\title{
Influence of Lean Management Practices on Quality in Construction Industries
}

\author{
T. Ravindaran, Dr.S. Anandakumar and Dr.V. Krishnamoorthy
}

\begin{abstract}
The purpose of this study is to determine various dimensions affecting quality in the application of Lean management practices in construction industries. This has been accompanied in South India from May 2015 to January 2016. The scholars implemented random sampling method for gathering data from the respondents. Moreover, questionnaire method has been used by the researchers. The researchers also used Statistical tools like Cronbach's Alpha, Exploratory factor analysis and multiple regressions for the study. This study significantly identifies nine important factors of quality in Lean implementation. They are: Elimination of waste, top management involvement, empower the team, timely delivery, amplify learning, material planning, employee ability, lean knowledge and quality of materials. Out of the identified factors: Elimination of waste, empowering the team and employee ability has significant impact on the project quality. The consequence of this research would benefit the policy makers in enclosing suitable procedures involving lean implementation in construction industries.
\end{abstract}

Keywords--- Elimination of Waste, Exploratory Factor Analysis, Material Planning, Multiple Regressions, Random Sampling

\section{INTRODUCTION}

$\mathrm{T}$ HE ineffectiveness in the industrial atmosphere has improved considerably and, as a direct concern, the search for different procedures and organization practices to achieve better performance in all processes have been a major concern for organizations involved in setting its global market presence. In order to survive with progressively more powerful competition, industrialized companies repeatedly try to expand their operations specific needs (Hallgren and Olhager, 2009).At one point of time, the world consolidated all continues quality improvement models under the title "Total Quality Management". In order to support TQM, several tactics, morals, methods and tools were evolved (Klefsjo et al., 2006).Lean engineering supports an institute to attain continuous development through the exclusion of nonvalue adding activities. Manufacturing firms functioning in the promptly changing and highly inexpensive market of the past

T. Ravindaran, Final Year M.E.(Construction Engineering and Management), Department of Civil Engineering, Kongu Engineering College, Perundurai, TamilNadu, India.E-mail:ravindaranthangavel@gmail.com

Dr.S. Anandakumar, Professor, Department of Civil Engineering, Kongu Engineering College, Perundurai, TamilNadu, India. E-mail:anandkeccivil15@gmail.com

Dr.V. Krishnamoorthy, Assistant Professor, Department of Management Studies, Kongu Engineering College, Perundurai, TamilNadu, India. E-mail:krishnamoorthydd@gmail.com

DOI: 10.9756/BIJIEMS.7089 two decades have involved the principles of Lean thinking. Increasingly more competitive surroundings and markets have required manufacturing associations to continuously search for improvements in their construction processes as an alternative to reducing working charges(Garza-Reyes,2010).Hines et al. (2004) define lean as the most influential new model in manufacturing. Lean production is embedded in the Toyota production system. Lean construction is a new idea oriented toward construction production administration (UsamaHamed Issa,2013).

\section{LITERATURE REVIEW}

Gao Shang and Low Sui Pheng(2014) concentrated on obstacles to lean application in the construction industry in China. Also they suggested that the most crucial barriers to application of lean performs, as real by Chinese building specialists, include "their deficiency of long-term thinking", "the lack of lean idea in their organizations", "the use of multi-layer contracting". Also shows the six underlying factors hindering the implementation of lean practices in the Chinese construction industry, namely, people and partner matters, managerial and organizational problems, lack of support concerns, beliefs and philosophy issues, government problems and procurement problems. Rania A.M. Shamah (2013) delivers assistance for the management of supply chains in order to upturn the chance of lean thinking being usually adopted for the purpose of value conception, and to scrutinise the potential role of the customer in educating supply chain performance. UsamaHamedIssa(2013) determined that the impacts of factors exaggerated by lean construction techniques declines with the increase in time. Jose Arturo Garza-Reyes, et al., (2012) studied the improvement of a lean park home construction process and compares the factory method to out dated on-site construction approaches. Raid Al-Aomar (2012) investigated the application of lean construction performs in the construction business and develops a practical and applicable framework that includes Six Sigma rating into the best performs of lean construction. Robert Conti, et al.,(2006) considered the effects of lean construction on employee work stress. The stress reduction and stress control opportunities identified in the study show the probable for designing and operating effective lean schemes while also controlling stress levels.

\section{RESEARCH GAP}

From the literatures collected, several studies have been done on Lean principles in the construction industries in several parts of the world and several conclusions have been made. But none of the studies have been done in South India 
about the application of lean principles in the construction industries. Hence, a study on application of Lean management principles in construction industries in India is necessary to make lean principles more efficient.

\section{Proposed Research Model}

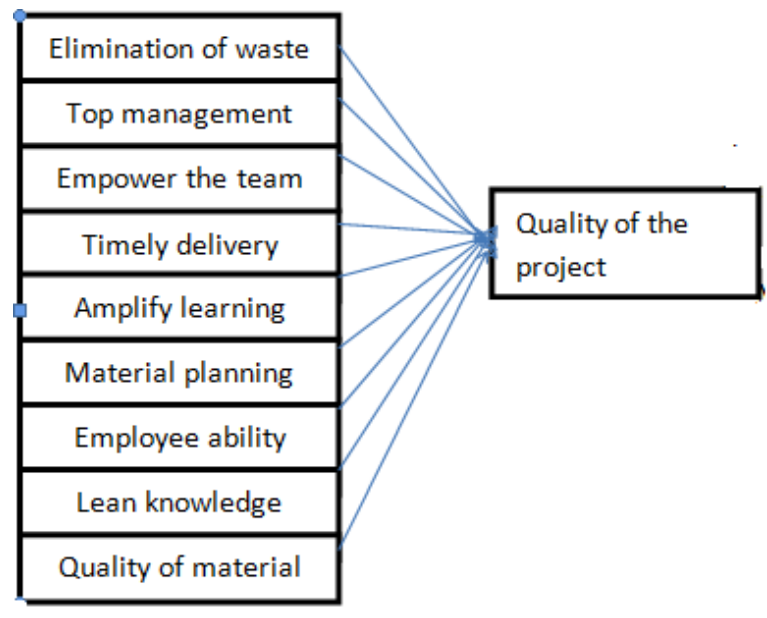

\section{OBJECTIVE}

- To identify the various factors leading to lean management practices in construction industries.

- To study the impact of various dimensions of lean management practices on quality of the project.

\section{PROJECT HYPOTHESIS}

$\mathrm{H}_{01}$ : There is no significant impact on elimination of waste on quality of the project.

$\mathrm{H}_{02}$ : There is no significant impact on top management involvement on quality of the project.

$\mathrm{H}_{03}$ : There is no significant impact on empower the team on quality of the project.

$\mathrm{H}_{04}$ : There is no significant impact on Timely delivery on quality of the project.

$\mathrm{H}_{05}$ : There is no significant impact on amplify learning on quality of the project.

$\mathrm{H}_{06}$ : There is no significant impact on material planning on quality of the project.

$\mathrm{H}_{07}$ : There is no significant impact on employee ability on quality of the project.

$\mathrm{H}_{08}$ : There is no significant impact on lean knowledge on quality of the project.

$\mathrm{H}_{09}$ : There is no significant impact on quality of material on quality of the project.

\section{Scope}

The scope of the paper is restricted to the project directors and managers of various construction firms in South India.

\section{Period of study}

The study was conducted during the period of May 2015 to January 2016.

\section{Data Collection Methods}

Major data collection was done through questionnaire survey. The first portion of the questionnaire comprises of Demographic profile of the respondents. The second part consists of the respondent views on the application of Lean principles in construction industries in South India. The third part consists of the business performance of the company.

\section{QUESTIONNAIRE FORMATION}

The variable relating to the present study is drawn from the previous work done by- (Gao Shang and Low Sui Pheng 2014), (GiulianoAlmeidMrodin and Tarcisio Abreu Saurin2015), (IngerGamme and SiljeH.Aschehoug 2014), (Koskela 1992), (LucilaM.S.Campos 2013), (ManimayGhosh 2013), (Rania A.M.Shamah 2013), (Robert Conti, Jannis Angelis, Cary Cooper, Brian Faragher and Colin Gill 2006).

\section{Pilot Study}

Before directing questionnaire to the respondents the academics directed pilot study. Based on the response received from project directors and managers of various construction firms, some modifications have been made in the prevailing questionnaire.

\section{Content Validity of Questionnaire}

The researcher constituted a committee that consists of an expert in Lean Construction and an academician. Based on their valuable suggestions some changes were made in the existing questionnaire.

\section{DATA ANALYSIS, INTERPRETATION AND RESULTS}

\section{Demographic Profile}

Within the perspective of the construction firms, some of the most frequently explored demographic variables are gender, experience, job position, nature of the project, form of business, years of existence, turnover of the company. An investigation of the gender composition of the respondents showed that 100 per cent of the respondents were male. Only 14.2 per cent of the respondents were having less than 3 years of experience while 33.6 per cent were between 3 and 5 years, with 23 per cent of the respondents were between 5 and 7 years and 29.2 per cent of the respondents were above 7 years.

\section{Reliability analysis}

The constant alpha scores were considered for evaluating reliability of the lean principles which are listed dimension wise in Table I. the coefficient alpha values for variables are well above the criterion as recommended by Nunnaly(1978) for assessing reliability of the scale.

Table I: Reliability Statistics

\begin{tabular}{|l|l|}
\hline Cronbach's Alpha & No. of Items \\
\hline 0.934 & 30 \\
\hline
\end{tabular}

\section{FACTOR ANALYSIS}

A principal component factor analysis with varimax rotation was performed on 30 variables that assessed the real lean management practices in construction industries. The 
statistical test result $(\mathrm{KMO}=0.664$, Bartlett's test of sphericity $=435.00$, significance $=0.000$ ) revealed that the factor analysis method was appropriate. The nine dimensions and the percentage of variance explained are listed in table

Table II : KMO and Bartlett's Test

\begin{tabular}{|c|c|c|}
\hline \multicolumn{2}{|c|}{ Kaiser-Meyer-Olkin Measure of Sampling Adequacy. } & 0.664 \\
\hline Bartlett's Test of Sphericity & Approx. Chi-Square & 2719.692 \\
\hline & Df & 435 \\
\hline & Sig. & 0.000 \\
\hline
\end{tabular}

Factor 1, which was labelled as elimination of waste, was composed of three variables and accounted for 21.207 per cent variance. Factor 2 consist of four variables that relate to the top management participation of lean practices and accounts for 9.357 per cent of the variance. Factor 3 was labelled as empower the team that includes three variables. It accounts for additional 8.750 per cent of variance. Factor 4 was timely delivery that contained three variables accounted for additional 7.026 per cent. Factor 5 was interpreted as amplify learning and comprised of four variables. It accounted for an additional 6.923 per cent of variance. Factor 6 was labelled as material planning. It consists of three variables and accounted for 6.547 per cent of variance. Factor 7 was named as employee ability that composed of three variables. It accounted for an additional 5.728 per cent of variance. Factor 8 and 9 was labelled as lean knowledge and quality of material which consists of four and three variables respectively.

Table III: Lean Application Quality Dimensions (LAQD)

\begin{tabular}{|l|l|l|l|l|l|}
\hline Sl.No. & LAQD & $\begin{array}{l}\text { No. of variables } \\
\text { included }\end{array}$ & $\begin{array}{l}\text { Eigen } \\
\text { value }\end{array}$ & $\begin{array}{l}\text { Percentage of variance } \\
\text { explained }\end{array}$ & $\begin{array}{l}\text { Cumulative percentage of } \\
\text { variance explained }\end{array}$ \\
\hline 1 & Elimination of waste & 3 & 32.858 & 21.207 & 21.207 \\
\hline 2 & $\begin{array}{l}\text { Top management } \\
\text { involvement }\end{array}$ & 4 & 9.781 & 9.357 & 30.563 \\
\hline 3 & Empower the team & 3 & 6.764 & 8.750 & 39.313 \\
\hline 4 & Timely delivery & 3 & 5.808 & 7.026 & 46.339 \\
\hline 5 & Amplify learning & 4 & 4.944 & 6.923 & 53.262 \\
\hline 6 & Material planning & 3 & 4.469 & 6.547 & 59.809 \\
\hline 7 & Employee ability & 3 & 4.347 & 5.728 & 65.537 \\
\hline 8 & Lean knowledge & 4 & 3.798 & 5.678 & 71.234 \\
\hline 9 & Quality of material & 3 & 3.395 & 4.930 & 76.164 \\
\hline
\end{tabular}

\section{Multiple REgRESSION ANALYSIS}

In order to test the influence of quality dimension of lean management practices in construction industries, multiple regression analysis was employed. Generally quality was used as the dependent variable even as the independent variables were represented by elimination of waste, top management involvement, empower the team, timely delivery, amplify learning, material planning, employee ability, lean knowledge and quality of materials. The compute command in SPSS version 20 was used to compute the value loadings associated with the variables measuring each of the factors based on numeric transformations in order to obtain values for both the dependent and independent variables. Table IV and table $\mathrm{V}$ presents a summary of the multiple regression results for the dependent and independent variables.

Table IV: Anova

\begin{tabular}{|ll|l|l|l|l|l|}
\hline Model & & Sum of Squares & Df & Mean Square & F & Sig. \\
\hline 1 & Regression & 164.033 & 9 & 18.226 & 23.476 & $0.000^{\circ}$ \\
& Residual & 79.967 & 103 & 0.776 & & \\
& Total & 244.000 & 112 & & & \\
\hline
\end{tabular}

The results indicate that there is a strong and significant relationship between quality of material and the lean management practices in construction industries $(F=23.476$, probability $F$ statistics $<0.000)$. The $R^{2}$ value $=0.672$ indicated that the independent variables explained 67.2 per cent of the variance in quality of the project with an adjusted $R^{2}$ of 64.4 per cent. On the

Table V: Influence of Lean Management Practices on Quality

\begin{tabular}{|c|c|c|c|c|c|}
\hline \multirow[t]{2}{*}{ Independent variables } & \multirow{2}{*}{$\begin{array}{l}\text { Standardized Coefficients } \\
\text { Beta }\end{array}$} & \multirow[t]{2}{*}{$\mathrm{t}$} & \multirow[t]{2}{*}{ Sig. } & \multicolumn{2}{|c|}{ Co linearity Statistics } \\
\hline & & & & Tolerance & VIF \\
\hline Constant & & -0.913 & 0.363 & & \\
\hline Elimination Of Waste & 0.587 & 5.869 & 0.000 & 0.318 & 3.147 \\
\hline Top Management & 0.154 & 1.765 & 0.081 & 0.418 & 2.393 \\
\hline Empower The Team & 0.355 & 4.069 & 0.000 & 0.419 & 2.387 \\
\hline Deliver As Fast As Possible & -0.087 & -1.401 & 0.164 & 0.826 & 1.210 \\
\hline Amplify Learning & -0.078 & -1.203 & 0.232 & 0.756 & 1.323 \\
\hline Material Planning & -0.004 & -0.065 & 0.949 & 0.699 & 1.430 \\
\hline Employee Ability & -0.234 & -3.029 & 0.003 & 0.535 & 1.870 \\
\hline Lean Knowledge & -0.055 & -0.871 & 0.386 & 0.811 & 1.233 \\
\hline Quality of material & 0.127 & 2.026 & 0.045 & 0.814 & 1.229 \\
\hline
\end{tabular}




\section{TESTING OF HYPOTHESIS}

The results of the testing of the hypothesis in the context of lean application criteria with nine factors are detailed in table VI.

Table VI: Testing of Hypothesis

\begin{tabular}{|l|l|l|l|l|}
\hline SL.NO & Hypothesis & T value & Beta & Results \\
\hline $\mathrm{H}_{01}$ & Elimination of waste will have no significant impact on quality of the project & 5.869 & 0.587 & Not conformed \\
\hline $\mathrm{H}_{02}$ & Top management involvement have no significant impact on quality of the project & 1.765 & 0.154 & Conformed \\
\hline $\mathrm{H}_{03}$ & Empower the team has no significant impact on quality of the project & 4.069 & 0.355 & Not conformed \\
\hline $\mathrm{H}_{04}$ & Timely delivery have no significant impact on quality of the project & -1.401 & -0.087 & Conformed \\
\hline $\mathrm{H}_{05}$ & Amplify learning has no significant impact on quality of the project & -1.203 & -0.078 & Conformed \\
\hline $\mathrm{H}_{06}$ & Material planning have no significant impact on quality of the project & -0.065 & -0.004 & Conformed \\
\hline $\mathrm{H}_{07}$ & Employee ability has no significant impact on quality of the project & -3.029 & -0.234 & Not conformed \\
\hline $\mathrm{H}_{08}$ & Lean knowledge has no significant impact on quality of the project & -0.871 & -0.055 & Conformed \\
\hline $\mathrm{H}_{09}$ & Quality of materials used has no significant impact on quality of the project & 2.026 & 0.127 & Conformed \\
\hline
\end{tabular}

\section{CONCLUSION}

This study has identified nine important factors of Elimination of waste, top management involvement, empower the team, timely delivery, amplify learning, material planning, employee ability, lean knowledge and quality of materials for lean implementation. Moreover, this study also established that there is a substantial association with Elimination of waste, top management involvement, empower the team, timely delivery, amplify learning, material planning, employee ability, lean knowledge and quality of materials. This study has some limitations. This paper considers only nine independent variables Elimination of waste, top management involvement, empower the team, timely delivery, amplify learning, material planning, employee ability, lean knowledge and quality of materials. This study consists of one dependent variable. In future similar studies could be conducted by adding more number of dependent variables. This study has been conducted only in South India. Similar study can be conducted throughout India. The findings of this research can be applicable to other sectors like manufacturing and production industries.

\section{REFERENCES}

[1] Aat van den Bos, Benjamin Kemper and Vincent de Waal, 'A study on how to improve the throughput time of Lean Six Sigma projects in a construction company', International journal of lean six sigma, Vol. 5, No.2, pp. 212-226, 2014.

[2] Bernard Kornfeld and Sami Kara, 'Selection of Lean and Six sigma projects in industry', International journal of lean six sigma, vol.4, No.1, Pp.4-16, 2013.

[3] Bhim Singh, S.K.Garg, S.K.Sharma and ChandandeepGrewal, 'Lean implementation and its benefits to production industry', International Journal Of Lean Six Sigma, Vol. 1 No. 2, Pp. 157$168,2010$.

[4] Eric Singer and Kurt Becker, 'A single-source content management system for lean manufacturing', International journal of lean six sigma, Vol.4, No.1, Pp.83-103, 2013.

[5] Dombrowski.U and Mielke.T, 'Lean leadership - 15 Rules for a sustainable Lean implementation', Procedia CIRP, Vol. 17, Pp. 565-570, 2014.
[6] Gaoshang and Low Sui Pheng, 'Barriers to lean implementation in the construction industry in China', Journal of technology management in china, Vol.9, No.2, Pp. 155-173, 2015

[7] George Besseris, 'Multi-factorial Lean Six Sigma product optimization for quality, leanness and safety', International journal of lean six sigma, vol. 5, No. 3, Pp.253-278, 2014.

[8] Giuliano Almeida Marodin and Tarcisio Abreu Saurin, 'Classification and relationships between risks that affect lean production implementation', Journal of Manufacturing Technology Management, Vol. 26, No. 1, Pp 57-79, 2015.

[9] Hallgren.M and Olhager.J, "Lean and Agile manufacturing: External and Internal drivers and performance otucomes", International journal of Operations \& production Management, Vol.29, No.10, Pp. 976-999, 2009.

[10] IngerGamme and Silje H. Aschehoug, 'Assessing lean's impact on operational integration', International journal of quality and service science", Vol.6, No.2/3, Pp.112-123,2014.

[11] Jose Arturo Garza-Reyes, IliasOraifage, Horiacio SorianoMeier, Paul L.Forrester, 'The development of a lean park homes production process using process flow and simulation methods', Journal of manufacturing technology management, Vol.23, No.2, Pp. 178-197,2012.

[12] JosteinPettersen, 'Defining lean production: some conceptual and practical issues', The TQM journal, Vol.21, No.2, Pp. 127142,2009 .

[13] Karthi.S and Devadasan.S.R, 'Integration of Lean Six-Sigma with ISO 9001: 2008 standard', International journal of Lean Sis Sigma, vol.2, No.4, Pp.309-331,2011.

[14] Klefsio.B, Bergquist.B and Edgeman.R.L, "Six Sigma and Total Quality management: different day, same soup?", International Journal of Six Sigma and competitive, Vol.2 No. 2, Pp. 162178,2006 .

[15] Lucila M.S. Campos, 'Lean manufacturing and Six Sigma based on Brazilian model "PNQ" An integrated management tool', International journal of lean six sigma, vol. 4, No. 4, Pp 355369, 2013.

[16] Malak Al Hattab and FarookHamzeh, 'Using social network theory and simultation to compare traditional versus BIM- lean practice for design error management', Automation in construction, Vol. 52, Pp. 59-69, 2015.

[17] ManimayGhosh, 'Lean manufacturing performance in Indian manufacturing plants', Journal of Manufacturing Technology Management, Vol. 24, No.1, Pp. 113-122, 2013.

[18] MohdArifMarhani, AiniJaapar and Nor Azmi Ahmad Bari 'Lean construction: Towards enhancing sustainable construction in Malaysia', social and behavioural sciences, Vol. 68, Pp. 87-98, 2012.

[19] Nunnally.J.C, Psychometric Theory, McGraw-Hill, New York, NY, 1978.

[20] Per Erik Erikson, 'Improving construction supply chain collaboration and performance: a lean construction pilot project', 
Supply Chain Management: An International Journal, Vol. 15 No.5, Pp. 394-403, 2010.

[21] Raid Al-Aomar, 'A lean construction framework with Six Sigma rating', An international journal of Lean Six Sigma, Vol. 3, No. 4, Pp.299-314, 2012.

[22] Rafael sacks,MilanRadosavljevic,Ronen Barak, 'Requirements for building information modelling based lean production management systems for construction', Automation in construction vol.19, Pp. 641-655, 2010.

[23] Randall G. Peteros and John Maleyeff , 'Using Lean Six Sigma to improve investment behavior', International journal of lean six sigma, vol.6, No.1, Pp.59-72, 2015.

[24] Rania A.M. Shamah, 'A model for applying lean thinking to value creation', International journal of lean six sigma, Vol.4, No 2, Pp. 204-224,2013.

[25] Robert conti, Jannis Angelis, Cary Cooper, Brian Faragher and Colin Gill, 'The effects of lean production on worker job stress',International journal of operations and production management, Vol.26, No.9, Pp. 1013-1038, 2006.

[26] UsamaHamedIssa, Implementation of lean construction techniques for minimizing the risks effect on project construction time', Alexandria engineering journal, 2013. 